\title{
First report of tomato spotted wilt virus on lisianthus (Eustoma grandiflorum) in Bulgaria
}

\author{
Gancho Pasev $^{1}$ (D) - Vesela Radeva-Ivanova ${ }^{1} \cdot$ Rafe Lyall $^{2} \cdot$ Amol Nankar $^{2} \cdot$ Dimitrina Kostova $^{2} \cdot$ Massimo Turina $^{3} \cdot$ \\ Marta Vallino ${ }^{3}$
}

Received: 24 February 2020 / Accepted: 12 November 2020 / Published online: 20 November 2020

(C) Società Italiana di Patologia Vegetale (S.I.Pa.V.) 2020

Keywords TSWV $\cdot$ Lisianthus $\cdot$ ELISA $\cdot$ RT-PCR $\cdot$ Bulgaria

Tomato spotted wilt virus (TSWV) is one of the most destructive pathogens worldwide. In Bulgaria the virus was found to severely damage a number of solanaceous vegetables and $c a$. 25 ornamentals (Hristova et al. 2001). In spring 2014, about $30 \%$ of lisianthus plants ( $\mathrm{ca} .1000$ plants) grown in a private farm nearby Plovdiv, Bulgaria showed yellowing and/or light brown necrosis on leaves and petals followed by subsequent wilting. To identify the causal agent of this infection, Chenopodium quinoa, Nicotiana glutinosa, and Petunia hybrida plants were sap inoculated with material from 10 symptomatic individuals. C. quinoa displayed large necrotic local lesions. Primary and systemic symptoms in $N$. glutinosa appeared as translucent necrotic lesions accompanied with yellow areas, while $P$. hybrida showed dark necrotic ring spots. Observations of lisianthus leaf sap by electron microscopy revealed the presence of isometric particles $c a .85 \mathrm{~nm}$ in size resembling those of tospoviruses. A TASELISA test was conducted with antisera specific for impatiens necrotic spot virus (INSV, RT-0115-0117/1) and TSWV (RT0105-0106/3) purchased from DSMZ, Germany. The samples from lisianthus and those from the inoculated indicators were positive only for TSWV. RNA was isolated from symptomatic leaves of lisianthus by TRI reagent ${ }^{\circ}$ (Sigma-Aldrich) and

Gancho Pasev

gancho_pasev@izk-maritsa.org; gipasev@aol.com

Maritsa Vegetable Crops Research Institute, 4003 Plovdiv, Bulgaria

2 Center of Plant Systems Biology and Biotechnology, 4000 Plovdiv, Bulgaria

3 Institute for Sustainable Plant Protection, National Research Council of Italy, I-1013 Torino, Italy reverse transcription (RT) was performed using random hexamer primers. The PCR amplification conducted with specific primers targeting $\mathrm{N}$ gene, described by Roberts et al. (2000), revealed an amplicon of about 600 bp corresponding to the expected size. Further, the amplicon was sent for sequencing. A high-confidence consensus nucleotide sequence of 567 bp (accession No. MK388405) was selected for analysis, which encoded a protein of 188 amino acids. This protein was queried against a database of all NCBI viral protein sequences by blastp and showed $99 \%$ sequence identity to TSWV nucleocapsid protein, including several accessions from Bulgaria (e.g. CAC01282.1, CAC01285.1) (Heinze et al. 2001). The results from TAS-ELISA and RT-PCR tests clearly show that the virus-specific antibodies do not have interspecies cross-reactivity. Based on our knowledge and viruses reported in literature, this appears to be a first report of TSWV on lisianthus in Bulgaria.

Acknowledgements The authors GP, VR-I, RL, ANN, and DK acknowledge the financial support of Horizon 2020 PlantaSYST project under the Grant Agreement No 739582.

\section{References}

Heinze C, Letschert G, Hristova D, Yankulova M, Kauadjouor O, Willingmann P, Atanassov A, Adam G (2001) Variability of the $\mathrm{N}$-protein and the intergenic region of the S RNA of tomato spotted wilt tospovirus. New Microbiol 24:175-187

Hristova D, Karadjova O, Yankulova M, Heinze C, Adam G (2001) A survey of tospoviruses in Bulgaria. J Phytopathol 149:745-749

Roberts CA, Dietzgen R, Heelan L, Maclean D (2000) Real-time RTPCR fluorescent detection of tomato spotted wilt virus. J Virol Methods 88:1-8

Publisher's note Springer Nature remains neutral with regard to jurisdictional claims in published maps and institutional affiliations. 